простого к сложному”, начиная с менее сложных научных текстов по специальности и менее сложных заданий, затем переходя к более сложным. Тексты повышенной сложности и задания к ним преподаватель может сформулировать самостоятельно, исходя из собственного опыта и потребностей студентов. Систематическая работа с текстом по специальности является ведущей составной частью обучения студентов на занятиях по русскому языку как иностранному как на основных курсах, так и практических занятиях. Это развивает навыки репродуцирования и продуцирования текстов и способствует формированию научной коммуникативной компетенции в профессиональной сфере.

Список испо льзо ва нно й лите ра туры :

1 С.И.Ожегов. Толковы й словарь русского языка. М-ва 2010.с 735.

2 М. М. Бахтин. Проблема текста в лингвистике, филологии и других гуманитарных науках. Опыт философского анализа. Бахтин М.М. Эстетика словесного творчества / Сост. С.Г.Бочаров; Текст подгот. Г.С.Бернштейн и Л.В.Дерюгина; Примеч. С.С.Аверинщева и С.Г.Бочарова. - Изд.2-е. - М.: Искусство, 1986. - с.297-325, 421-423 (прим.).

3 Выготский Л.С. Мышление и речь. Психологические исследования. Питер 2019 г, с. 279.- книга

4 Новый словарь методических терминов и понятий (теория и практика обучения языкам).

М.: Издательство ИКАР. Э. Г. Азимов, А. Н. Щукин. 2009

5 Ярица Л.И. “ЧИТАЕМ НАУЧНЫЕ ТЕКСТЫ ПО-РУССКИ” [5, с. 20]. Издательство Томского политехнического университета 2012

6 Ярица Л.И. “ЧИТАЕМ НАУЧНЫЕ ТЕКСТЫ ПО-РУССКИ” [5, с. 72-74]. Издательство Томского политехнического университета 2012

References:

1 S.I. Ojegov. Tolko vyi slo var rusko go iazyka. M-va 2010.s 735.

2 M. M. Bahtin. Problema te ksta v lingvistike, filo lo gii i drugih guma nita rny ha naka h. Opyt filo so fsko go a naliza. Bahtin M.M. Estetika slovesnogo tvorchestva / Sost. S.G.Bocharov; Tekst podgot. G.S.Bernstein $i$ L.V.Derugina; Primech. S.S.Averinseva i S.G.Bocharova. - Izd.2-e. - M.: Iskustvo, 1986. — s.297-325, 421-423 (prim.).

3 Vygotski L.S. Mysle nie i rech. Psiho lo gicheskie issle do va nia. Piter 2019 g, s. 279

4 Novyi slovar me to diche skih terminov i ponAti (te o ria i praktika obuchenia iazykam). - M.: Izda telstvo IKA R. E. G. Azimov, A. N. Sukin. 2009.

5 Iarisa L.I. "CHITAEM NAUCHNYE TEKSTY PO-RUSKI” [5, s. 20]. Izdatelstvo Tomskogo polite hniche sko go unive rsite ta 2012

6 Iarisa L.I. "CHITAEM NAUCHNYE TEKSTY PO-RUSKI” [5, s. 72-74]. Izdatelstvo Tomskogo po lite hniche sko go unive rsite ta 2012

МРНТИ 16.21.21

https://doi.org/10.51889/2021-1.1728-7804.58

\author{
Yermekbayev M., ${ }^{1}$ Koishibaeva N. ${ }^{2}$ \\ ${ }^{1,2}$ South-Kazakhstan university named after M.Auezov, \\ Shymkent, Kazakhstan
}

\title{
PEDAGOGIGAL ASPECTS OF THE FORMATION LINGUISTIC AND CULTURAL COMPETENCE
}

\begin{abstract}
The main result of the learning process in primary school depends on how many competencies the student has mastered. a student who has developed linguistic and cultural competencies is immersed in the grammatical structural secrets of the Kazakh language, understands the laws of applying certain grammatical rules in speech, and learns the mechanism of sentence formation. And without competence, the undocumented skills of theoretical complementarity are transformed into the preparation of a single plateau. On a conscious scale, students ' language competencies become a necessary condition for organizing their language skills and abilities. Properly formed language and cultural competencies help students to understand the studied phonetic, lexical, grammatical phenomena in depth, to understand the mechanism of Word formation, correct spelling rules, the presence of certain types of speech in the language presence, syntactic structures, etc.
\end{abstract}

Keywords: education, primary school education, Kazakh language teaching, vocabulary approach, language competence, formation of language competence 


\author{
Ермекбаев М.А., ${ }^{1}$ Қойшыбаева $H^{2}$ \\ ${ }^{1,2}$ М. Әуезов атындавы Оңзтүстік Қазақстан университеті , \\ Шымкент, Қазақстан
}

\title{
ОҚУШЫЛАРДЫН ТІЛДІК-МӘДЕНИ КҰЗІРЕТІН ҚАЛЫПТАСТЫРУДЫН ПЕДАГОГИКАЛЫҚ НЕГІЗДЕРІ
}

Бастауыш мектептегі оқыту үдерісінің негізгі нәтижесі оқушының қаншалықты құзіреттілктерді игергеніне байланысты. тілдік - мәдени құзіреттілктері қалыптасқан оқушы қазақ тілінің грамматикалық құрылымдық құпиясына енеді, қандай да бір грамматикалық ережелерді сөйлеуде қолдану заңдылықтарын түсінеді, сөйлемнің құрылу механизмін меңгереді. Ал құзіреттіліксіз теориялық толықтырудың құжаттандырылмаған біліктері бір өзі үстіртін даярлауға айналып кетеді. Саналы көлемде оқушылардың тілдік құзіреттіліктері олардың тілдік қатысым дағдылары мен біліктерін ұйымдастырудың қажетті шарты болып келеді. Дұрыс қалыптасқан тілдік-мәдени құзіреттіліктер оқушыларға оқытылып отырған фонетикалық, лексикалық, грамматикалық құбылыстарды терең ұғынуға көмектеседі, сөз құралу механизмін түсінуге, дұрыс жазылу ережесін, тілдік қатысымның қандай да бір сөйлеу түрлерінің болуын, синтаксистік құрылымдарды және т.б. жете ұғынуына көмектеседі.

Түйін сөздер: бастауыш мектеп оқушылары, бастауыш мектеп оқушыларының тілі, психолингвистика, бала тілінің дамуы, бастауыш мектеп оқушыларының тілдік қалыптастыру мәселесі

\author{
Ермекбаев М.А., ${ }^{1}$ Койшыбаева . $^{2}$ \\ ${ }^{1,2}$ Южно-Казахстанский университет имени М. Ауезова, \\ Шымкент, Казахстан
}

\section{ПЕДАГОГИЧЕСКИЕ ОСНОВЫ ФОРМИРОВАНИЕ ЛИНГВОКУЛЬТУРНОЙ КОМПЕТЕНЦИИ УЧАЩИХСЯ}

Основной результат процесса обучения в начальной школе зависит от того, насколько компетентен ученик. Обучающийся, у которого сформированы лингвокультурные компетенции, погружается в грамматическую структуру казахского языка, понимает закономерности употребления в речи тех или иных грамматических правил, овладевает механизмом построения предложения. А недокументированные умения теоретического дополнения без компетенции превращаются в одно самообразование. В осознанном объеме языковые компетенции учащихся являются необходимым условием организации их умений и навыков речевого общения. Правильно сформированные лингвокультурные компетенции помогают учащимся глубже понять изучаемые фонетические, лексические, грамматические явления, понять механизм словообразования, правила правильного написания, наличие тех или иных видов речевого общения, синтаксические конструкции и др.

Ключевые слова: образование, образование в начальном школе, преподавания казахского языка, словарный подход, компетенция, формирование компетенции учащихся

Introduction. The work on the formation of language and cultural competence of primary school students was carried out through didactic principles. Didactic principles are the basis for the organization of the learning process, the Kuality of knowledge, the effective use of teaching aids and methods in the classroom.

Methods.Didactic scholars divide didactic principles into more than a hundred types and distinguish the peculiarities of each according to its purpose [1], [2], [3], [4], [5].

The scientist A.Isabayev noted that in the implementation of didactic principles, the teacher observes two main principles: first, students' conscious understanding of learning materials, active participation of students, and second, the teacher's visual aids, systematic interpretation of the lesson in terms of activities. He believes that the lessons should be based on the following principles: scientific, systematic, visual, linking theory with practice, easy to understand, taking into account the mental characteristics of students [6, 8-11].

Zh.Koyanbayev and R.Koyanbayev add two new principles to the above principles. The first is the principle of comprehensibility, the second one is the principle of purposefulness of the learning process [7, 204-215].

S. Rakhmetova, G. Uaisova, A. Zhumabayeva and other scientists studied scientifically the methods of teaching the Kazakh language in primary school. Methodologists recommend the implementation of the above principles of 
teaching: the principle of comparing the meaning of a word with the being it represents, the semantic-lexical or lexical paradigm, the principle of attention to the nature of language, the principle of understanding the meaning of words.

Depending on the purpose and specificity of our work, the following pedagogical principles were identified: strengthening the unity of theory and practice, maintaining the hierarchy in the learning process, improving students' own views and worldviews, developing students' skills of creative performance, emphasis on students' speech culture. The principles of mastery play a leading role.

Research result. Now let's focus on these didactic principles:

1. On the principle of strengthening the unity of theory and practice, the content of language materials in the textbook is taken into account in accordance with the concepts in the field of language and their structure. The connection "Knowledge is life" and effective methods are used in the analysis and teaching of real-life examples.

2. The principle of hierarchical continuity in the learning process is based on the development of knowledge and skills acKuired by students from easy to difficult, from simple to complex. The data used in the study of language materials were continued.

3. The principle of improving the student's own views and worldview is not given to students in a ready way, but is aimed at the development of their search, independence, creative thinking.

4. According to the principle of paying attentionto the culture of speech of students, the etiKuette in a particular situation reKuires compliance with the rules inherent in the order of communication, spelling. One of the main goals of teaching regional geography in primary school is not only to form in students a sense of etiKuette, but also to master the norms and principles of etiKuette, passed down from generation to generation, to lay the groundwork for polite and courteous speech. Therefore, it is necessary to master the skills of speech culture in each lesson, creating conditions for students to feel freedom of speech, freedom of thought, to express themselves openly and clearly. According to this principle, the primary school teacher should listen to and understand what someone else is saying. Moreover, they able to express their thoughts clearly, accurately, and read, understand the textbook and fiction, then express their thoughts. Finally, it is necessary to develop the skills of oral communication in linguistic communication.

5. The student is reKuired to perform the creative task in accordance with the purpose according to the principle of developing students' skills of creative performance of topics. Students can learn that the art of speech is more important than other types of art. Creative work encourages the child to accept all the good and beauty that he has seen and noticed. The teacher keeps this in mind when organizing creative work. Creative work should not be expected from students with insignificant phrases "write a poem in class today" or "write a story". And how to create creativity? The teacher should:

- talk to a child as eKuals, be very close;

- always hope for them saying the phrases "You can" and "I believe in you" and to express confidence;

- Assessment of student opportunities, encouragement of achievement;

- read a poem to arise their interest, ask Kuestions to find out the child's thoughts, tell interesting stories, etc .;

- get into a situation with students in order to introduce them to the world of art of speech;

- The teacher's relationship with the student in creative work of non-linguistic aspects (view, feelings, smiles, facial expressions, etc.).

The educational aspect of the work is taken into account when forming a creative state. For example: the task from the 4th grade on the "Kazakh language" is given to write an essay on the theme "The waters of our land".Kuestions were asked using the "Demonstration" method to rise students' interest. Two different images are displayed. The first picture shows a desert, and the second picture shows green trees, wetlands, and beautiful scenery. In order to inspire, the following Kuestions were asked:

- Which of these two pictures do you like?

- Why do you like it?

- And why don't you like this picture?

- Why is this place in such a state?

- Can a beautiful land turn into a desert?

The students answered the last Kuestion and gave their opinions. These Kuestions opened the topic of a new lesson. I liked the work of one student. He spoke about the Arys River and its poor ecological condition. This work is more than a work of research. Two tapes were shown to complement this topic. In one of them, there is a gurgling river, on both sides of the river there are thick trees, flying birds, thick reeds, etc. There are people who have gathered their belongings, people who are fishing. When students who have seen these scenes are asked to draw their own conclusions, they say, "Water is the source of life. There is life in the wetlands."

In the second video, the riverbank is cloudy and polluted. Fish are dying because of the waste, and birds are dying on the shore. There are people leaving the rubbish after the weekend. According to the video, the children responded to the extracurricular educational event by saying "People do not have a day without nature, there is no language of nature to say this."

In order to continue this work, we went on a trip to the banks of the Arys River. As a result, if we can stimulate the student to search, then the child develops the ability to think in the textbook, not only think about what he saw, but also summarizes and answers students' Kuestions. Develops the ability to speak in public. 
It was possible to eliminate inappropriate words and stylistic errors used by students using the method of "Kultokpe"(rubbish bin). For example: the words such as "baldar" (guys) and "otkan"(sitting) we agreed to throw away and stop using them.

The "Rules of Success" were approved for the performance of creative work organized jointly with children:

- Read a lot.

- Do not use words that you do not know.

- Do not repeat one word, one idea.

- Do not confuse inappropriate words, adjectives.

- Competent writing in literary language.

- Concise, polite thinking.

- Reporting themselves, accepting criticism from friends.

- To be friends.

The work was carried out as a result of dialogue between teacher-student, student-student, student-parent in the field of language communication.

Discussion. The role of visual principles in the formation of linguistic and cultural competencies of students has a special place. Demonstrations are often used in primary school because the child's mind is not yet fully formed and needs to rely on real images. The purpose of illustration is not to explain things themselves, but to use them as a basis for explaining certain material. Because of the age of the child, he will not be able to master reading tasks on his own without relying on visual aids. This is because it is easier for a child to perceive a real image than an abstract image. This feature is common not only in the first grade, but also in all primary school students.

Demonstrations in the classroom do not always work, so it is better to combine the oral interpretation of the content of the study with the demonstrations, alternating one to another. If the teacher is constantly presenting the lesson material orally, then due to the strong excitation of a certain center of the student's brain, it becomes slower and faster. And if the content of learning is constantly changing, both verbally and visually, then not only one giant of the brain, but also other centers will be added in turn, and students will be absent for a long time during the lesson.

The work on the formation of language and cultural competence of school children is carried out regularly in the Kazakh language and literature classes. One of the most important functions of visual aids for the formation of linguistic and cultural competence of primary school students is the use of certain language materials. One of the motivations for students to speak in the classroom is the picture, if the picture is made in accordance with aesthetic reKuirements, its theme and images correspond to the grammatical form and construction reKuired by the program, it will be successful in shaping students' linguistic and cultural competence.

Distributed pictures are an effective form of visual aids for in-depth study of English language materials in accordance with these reKuirements, the formation of linguistic and cultural competence of students. This includes tasks related to the topic of the material, the image of the object or phenomenon, as well as the formation of skills to determine the meaning of a particular word and its correct use, enriching the vocabulary of the student. The Kuestion in the picture may come not only from the vocabulary, but also from other areas of linguistics. For example, in Grade 4, during the exercise on the topic of "Verbs", students are asked to reveal the meaning of the verbs "hear" and "be heard" in the picture, to make sentences involving the verbs in the dialogue of children talking on the phone. Such work allows to understand the meaning of words, to remember the rules of spelling, to check the level of mastery of the material, to develop the skills of communication in the presentation of the content of the given picture.

Video materials are one of the most effective visual aids in the formation of language and cultural competence of primary school students. Videos also consist of a set of visual materials. The main purpose of its use is to promote the development of language and cultural competence of primary school students, as well as the formation of literate writing skills, the formation of communicative speech. The content of each frame, which is given to students, reKuires accurate and accurate verbal description. Completion of this task will allow you to test your knowledge of the norms of literary language. Therefore, in order to reveal the content of each frame, the goal is to use the language materials mastered in connection with the object or phenomenon depicted in it.

For example, you can use the following frames when passing verb tenses.

1] A woman standing on the street with hand luggage looking at the driver from the cab window with a Kuestioning look.

2] A bright-faced driver who opened the cab door and asked the woman to get in the car.

The teacher shows the shots one by one and asks one of the students to describe the course of action in the shots in the past tense and the other in the present tense. As a result, students gain a deeper understanding of the language material [verb tenses] through practical use, and learn to communicate systematically.

The use of visual aids in the classroom corresponds to the psychological basis for the formation of language and cultural competence of students, facilitates the development of long-term memory, as it allows you to systematically work with lexical material included in the active vocabulary.

Although lessons for the formation of language and cultural competence of primary school students can use visual aids for language development, these tools differ in content and purpose, as these visual aids are designed to develop other skills and abilities of the student. 
The main purpose of connecting speech is not only to write a summary and composition, but also to develop specific language skills, first of all to understand the topic and convey the main action and event in it in different genres [reporting, description, reasoning].

Interactive whiteboards are widely used in schools to write summaries and essays. If the structure and content of the visuals are related to a specific type of creative work aimed at writing summaries, slides and movies serve as a stimulus to describe what you see. Any textbook used as a language stimulus should be age-appropriate in terms of clarity and structure of the author's thought.

The use of visual aids that facilitate the creation of a natural need for communication during independent creative work [the final stage in the formation of linguistic and cultural competence of primary school students] is a prereKuisite for the formation of linguistic and cultural competence of primary school students, especially oral language.

Each of the above activities has its own opportunities to motivate students to create their own pronunciation: if the speech has a clear and expressive rhythm of the voice, the picture and video give additional creative inspiration to the graphics: the combination of words and images.

Film is the most important tool for the formation of language and cultural competence of primary school students. Because there is a harmony between video and audio, the video is in action, and the audio is complemented by music. However, in the final stages of language development, visualization is needed to motivate [motivate] the desire to express what one has seen and heard and one's attitude to it, as well as to facilitate creative pursuits and facilitate it. In order to practice oral presentation, it is useful to use audio texts in the genre of short and interesting plot, open and clear voice rhythm. Oral narratives are composed in the genre of informative, in the text of the plot, which is not interrupted from the most interesting and decisive part of the story, using sound recordings that lead the listener to creative imagination. The content of the story should instruct the young author to develop a new version of the story line and complete it in a logical system. [For example, sad or happy is resolved].

The materials presented for the training of oral communication also vary depending on their specifics. At the initial stage, the preparatory exercises use successful or unsuccessful answers to Kuestions about a particular action or event, the author's arguments to defend his point of view, the following notes. In order to encourage students to express their opinions, it is helpful to listen to notes that compare conflicting views on a particular event. Such recordings engage the audience in a debate, forcing them to determine the direction of the action under discussion, to side with a particular point of view. Filmstrips for each stage of storytelling are different in content and structure. For the first training exercises it is better to use an interesting plot, which is perfect in terms of construction. Each frame is explained verbally, explaining the relationship between the stages of development of the action and the event: it facilitates the perception of the visual material as a whole. In order to write a creative story in English, they use unfinished or fullplot, but subtitled films. Each of these options helps to improve the plot and explain it verbally, to reveal to young viewers their own creativity. Filmstrips that teach storytelling in a systematic way should be engaging and engaging in terms of content.

One of the motivations for students to talk is a movie. Its peculiarity is due to the plot structure and the ability of the protagonist to sound [speak] and the musical accompaniment.

When using visual aids, the teacher should combine verbal descriptions of the object and phenomenon [or its image]. Because the visuals are definitely dumb. This sharing of feelings and words is a prereKuisite for children to recognize the individual in general, the individual in general. The teacher not only introduces the features and details of the object, but also explains its features. A teacher's speech is more powerful than a visual aid, because it can fully cover the necessary details that the author of the illustration did not take into account.

Conclusion.To draw the conclusion, the purpose of the formation of linguistic and cultural competence of primary school students is the organization of research activities of students through cultural materials, increasing student engagement, the formation of skills for independent learning, development of creative and logical thinking, language and cultural competencies.

\section{References:}

1 Turgunbaeva B. A. Technologies of developing learning A.: 2000.- 90 P. -book

2 Kukushin V.S. Modern pedagogical technologies. The beginning of the school. Thanks for the teacher. Rostovon - Don: Phoenix, 2004. - 384 STR.

3 Kushimbetova S. A. Pedagogical conditions for the use of innovative teaching methods in the educational process. Dissertation for the degree of candidate of Pedagogical Sciences. Almaty, 2004. - 154 P.

4 Kurmanova N. Scientific and methodological foundations of the technology of developing the syntax of phrases in Kazakh schools. Dissertation for the degree of Doctor of Pedagogical Sciences. Almaty, 2004. - 369 P.

5 Alimzhanov D., Mamanov I. methods of teaching the Kazakh language, Almaty: shul, 1996, $248 P$.

6 Isabaev A. Didactic bases of teaching the Kazakh language. Almaty: Kazakh University, 1993, 160 P.

7 Koyanbayev Zh. Koyanbayev R. Pedagogy. Astana. ENU 1998-378 P. 


\author{
Жолдасова А.А., ${ }^{1}$ Хайргельдина А.К. ${ }^{2}$ \\ ${ }^{1,2}$ НАО “Университет Нархоз”, \\ Алматы, Казахстан
}

\title{
ИСПОЛЬЗОВАНИЕ ТЕХНОЛОГИИ "ПИСЬМО И МЫШЛЕНИЕ" КАК СПОСОБ РАЗВИТИЯ КРИТИЧЕСКОГО МЫШЛЕНИЯ ПРИ ИЗУЧЕНИИ ДИСЦИПЛИН ОБЩЕОБРАЗОВАТЕЛЬНОГО ЦИКЛА
}

\section{Аннотация}

Статья посвящена вопросу использования технологии “Письмо и мышление” при изучении дисциплин общеобразовательного цикла в неязыковых вузах. Современное образование в последнее десятилетие подвергается трансформации и переосмыслению как в области учебно-воспитательного процесса, так и в общественном сознании в целом. Образование по модели свободных искусств и наук отвечает современным требованиям, предъявляемым к выпускникам вузов, которые должны обладать в полной мере комплексом социокультурных, коммуникативных и ценностно-смысловых компетенций. Данная модель обучения меняет и роль преподавателя, который традиционно воспринимался как транслятор учебной информации в одностороннем порядке. Центральное место при таком подходе к образованию занимает работа с текстом. Чаще всего таким текстом выступают не параграфы из учебников и учебных пособий, а тексты первоисточники (статьи авторов по изучаемой теме, документальные первоисточники и др.).

Ключевые слова: либеральное образование, критическое мышление, письмо и мышление, текстыпервоисточники, интерактивные методы обучения, техники письма, “Письмо в зонах”, модульные дисциплины

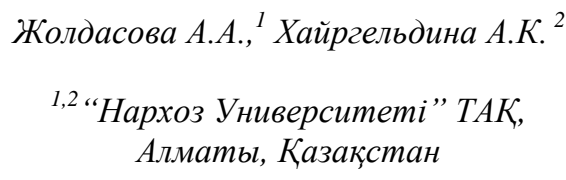

\section{ЖАЛПЫ БІЛІМ БЕРЕТІН ЦИКЛДАҒЫ ПӘНДЕРДІ ОҚЫТУ ҮШІН “ЖАЗЫЛЫМ ЖӘНЕ ОЙЛАУ” ТЕХНОЛОГИЯСЫН СЫНИ ТҰРҒЫДАН ОЙЛАУ ДАҒДЫСЫН ДАМЫТУДЫН ӘДІСІ РЕТІНДЕ ПАЙДАЛАНУ}

Мақала тілдік емес университеттердегі жалпы білім беру циклінің пәндерін оқытуда “Жазылым және ойлау” технологиясын қолдануға арналған. Соңғы онжылдықта заманауи білім беру процесі оқу-тәрбие ісінде де өзгеріске ұшыраған және оның тұтастай алғанда қазіргі қоғамның дамуындағы рөлі де түрленген. Өнер, ғылым мен модель бойынша білім беру әлеуметтік-мәдени, коммуникативті және құндылық-мағыналық құзыреттіліктің толық спектріне ие болуға тиісті университет түлектеріне қойылатын заманауи талаптарға сай келеді. Оқытудың бұл моделі оқу ақпаратын дәстүрлі түрде таратушы ретінде ғана біржақты қабылданған оқытушының да рөлін өзгертеді. Білім беруге қатысты мұндай тәсілде мәтінмен жұмыс істеу негізгі орынды иеленеді. Көбіне мұндай мәтіндер оқулықтар мен оқу-әдістемелік құралдардың параграфтары болмайды, керісінше мәтіндер- бастапқы дереккөздер (зерттелетін тақырып бойынша авторлардың мақалалары, деректі бастапқы көздер және т.б.) болып табылады.

Түйін сөздер: либералды білім беру, сыни тұрғыдан ойлау, жазылым және ойлау, бастапқы мәтіндер, оқытудың интерактивті әдістері, жазу техникасы, “Зоналарда жазу”, модульдік пәндер

\author{
Zholdassova A., ${ }^{1}$ Khairgeldina $A .^{2}$ \\ ${ }^{1,2}$ Non-profit joint stock company "Narxoz University", \\ Almaty, Kazakhstan
}

\section{USE OF "LETTER AND THINKING" TECHNOLOGY AS A METHOD FOR DEVELOPING CRITICAL THINKING IN STUDYING DISCIPLINES OF THE GENERAL EDUCATIONAL CYCLE}

\section{Abstract}

The article is devoted to the use of the technology "Writing and Thinking" in studying disciplines of the general education cycle in non-linguistic universities. In the last decade, modern education has been undergoing transformation 